\title{
Simulation of Cross Flow Heat Exchanger for Multi Tubes Using FLUENT 6.3.26
}

\author{
Suneela Sardar, Shahid Raza Malik \\ NFC Institute of Engineering and Fertilizer Research, Pakistan \\ crosgref $\mathrm{http}: / / \mathrm{dx}$. doi.org/10.5755/j01.erem.63.3.4453
}

(Received in May, 2013; accepted in September, 2013)

\begin{abstract}
In chemical engineering a lot of work is done to improve the results of the equipment to make its widespread applications be possible. Simulation is extensively used as the power of the computer is well known nowadays. Simulation is frequently used to study both real and virtual behavior. In this paper experimentation, simulation and development of mathematical models are performed. Practical experiments are made on a cross flow heat exchanger for a multi tube layout with staggered arrangement to study the rate of heat transfer. Simulation is carried out when experimental results are obtained. For designing and meshing of plate geometries GAMBIT 2.3.16 is used and then solution and analysis are accomplished on FLUENT 6.3.26. By comparing experimental and simulated results, it is found that both validate each other with minor differences. Empirical relationships have been also developed. $\mathrm{Re}$ and $\mathrm{Nu}$ relationships are developed mathematically and compared to the models found in literature concerned. The developed models are found in good agreement with theoretically available models. The future research in this regard can be done by using viscous fluids and an advanced version of the software like Cubit for designing and meshing the plate geometry.

Keywords: simulation, cross flow heat exchanger, Reynolds number, heat transfer coefficient, empirical relationship.
\end{abstract}

\section{Introduction}

Heat exchangers add or remove thermal energy and control the temperature of a system or substance. In cross flow heat exchangers use of air is its major advantage, as water in them is eliminated. Impersonation of an observable fact with the help of a device used in engineering is called simulation. To avoid the costly, time consuming and troublesome behavior of hit and trial practice, simulation is appreciable. Using the engineering relationships like phase and chemical equilibrium, balances of mass and energy, the process simulation can predict the performance of any process. Treatment of the core of a heat exchanger like a fluid zone using heat transfer $\&$ momentum is performed in FLUENT.

Loss in pressure and transfer of heat is modeled using the momentum and energy equation.

W Clark and D DiBiasio (2007) have started that learning can be improved by providing a link between theory and experimentation by using process simulation. Solutions of the problems involving complex relationships do not require expertise, as the advancement in computer and the development of equations solver along with GUI (Graphical User Interface) are sufficient [1]. J Wen and Y Li (2006) investigated the patterns of the flow numerically and experimentally in a plate and fin heat exchanger. Through CFD (Computational Fluid Dynamics) a simulation turbulent flow was distinguished at the inlet of a plate fin heat exchanger. The chain of velocity vectors and graphs is obtained for three different settings and found that a punched baffle based improved setting is better as compared to the traditional one. It is concluded that CFD simulation and experiments can deal with complicated flows and optimize the plate and fin heat exchanger design [2]. Y H Yoon (2009) theoretically analyzed and simulated the CFD in a ceramic monolith heat exchanger. Methods of NTU (Number of Transfer Units) and numerical computation are used to study the drop in pressure and performance of heat transfer 
in a ceramic monolith heat exchanger. The latter was examined to check the performance through a traditional method of NTU and $\mathrm{Nu}$ for a rectangular shaped duct. NTU method's effectiveness validates the numerical computation. [3] L Cabezas-Gomez and H A Navarro (2009) featured a new arrangement of a cross flow and thermally characterized the cross flow heat exchanger. The new arrangement possesses double rows of tubes with double lines, thus two fluids can flow in these circuits. Its performance was compared to the arrangement of the counter cross flow. The projected flow arrangement conveys high effectiveness thermally and efficiently and gives less value of entropy for an extensive range of capacity rate ratio, and NTU [4].

M Kim, Y Baik and S Park (2010) made experiments on plate heat exchangers which are cooled with air in a cross flow type. Two samples of plate heat exchangers are manufactured consisting of single and double wave plates in their stack. These are a good replacement of open loop based cooling towers in which water movement is in a closed loop; clean and compact are their properties. Tests on both samples were carried out in laboratory. Improvement in the performance up to $50 \%$ is noted in a double wave heat exchanger than that of a single wave type. [5] G Zhang and S Zhou (2006) analyzed and simulated the patterns of the flow in a cross corrugated plate type heat exchanger. Simulation of the angle of inclination of corrugation for corrugated plates was performed and numerical methods were applied. Results obtained from simulation show direct relationship between the patterns of the flow and the angle of inclination. Experimental results found in literature are also matched with the simulated ones. The patterns of flow show the zigzag movement when an angle of inclination is increased. [6] C Liang and $\mathrm{G}$ Papadakis (2007) studied large eddy simulation in a staggered tube in the cross flow arrangement at subcritical Re. The properties of vortex shedding are studied through this technique. The value of $\mathrm{Re}$ is 8600 and six rows of tubes in a staggered arrangement are present. The method of finite volume is applied to solve the equations in an unstructured arrangement of the grid by using the second order methods in time and space. Recirculation zones' sizes are compared to the already found correlations. Strouhal numbers obtained from them matched well with the values found in literature for similar arrangement. [7] $\mathrm{M} \mathrm{H}$ Saber and H M Ashtiani (2008) simulated and analyzed the CFD of heat pipe HX (Heat Exchanger) to enhance thermal efficiency in FLUENT. Performance of the evaporator of heat pipe HX was analyzed by using computational CFD, and the optimum flow distribution was also studied in this type. Principles of CFD are suitable and efficient due to the usage of finite volume for the solution of processes in transport phenomenon. Results are shown graphically and all the data are computed numerically using FLUENT. All the data obtained are compared to the existing data of heat pipe HX. [8]

D Egeregor (2008) used FLUENT as a tool for CFD analysis and studied the drop in pressure and simulated numerically the plate heat exchanger. For turbulent and transitional ranges of $\mathrm{Re}$, corrugated walls are to enhance the transfer of heat and mass, and they are efficiently applied in this regard. Wave geometry and chevron design heat exchangers were analyzed in FLUENT while GAMBIT was used for preprocessing. The wall temperature was taken constant and the working fluid used was water for both cases and then studied effect of Re. The Re range for simulation is 100 to 25600. [9] A Vali and C J Simonson (2009) developed a steady state numerical model in 2D for heat transfer study to recover the heat in heat exchangers combined with cross and counter flow arrangement of plates and membranes.

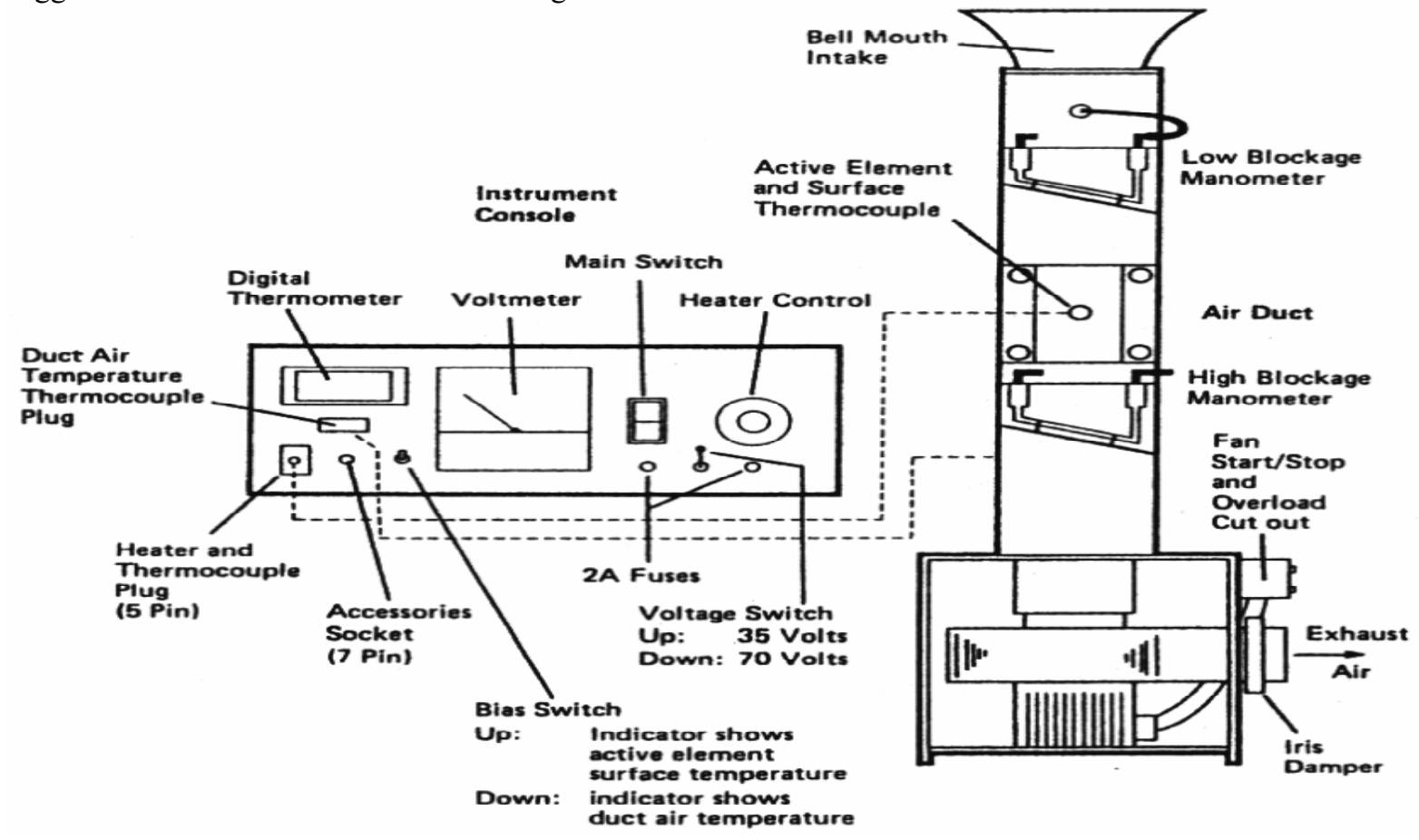

Fig.1. Cross Flow Heat Exchanger 
Continuity equations in steady state for the momentum and heat transfer are solved through the method of finite differences. Effectiveness of Run around HX lies between similar systems having two cross or counter flow HXs. Achievement of the greatest overall effectiveness is possible with those exchangers which have a small value of the aspect ratio and small lengths at inlet and exit. [10] $\mathrm{H}$ Mori (2010) enhanced the transfer of heat in a ground source heat pump. A modified design of the geothermal heat pump is provided with better feasibility. If the underground construction is not deep, then thermal energy is collected efficiently in a ground loop system to the horizontal direction. For performance enhancement important parameters were depicted from the results. Conductance of soil around the heat exchanger was found in the laboratory for improving the parameters. Optimization of the design coupled with CFD for the selection of the best modified design was done. Moisture content in the soil should be at an optimum level to efficiently collect the heat and modify practically and economically. [11] M Dehghandokht and M G Khan (2011) numerically analyzed the flow and heat transfer properties for meso channel HX in a multiport serpentine. Coolants used are water and mixture of ethylene glycol and water. Data of transfer of heat, drops in temperature and pressure in the case of coolants are numerically predicted, the core temperature in the bends of serpentine validates the experimental data. The existence of serpentine bend enhanced the rate of heat transfer up to $20 \%$ in mesochannel HX, not the straight bend of the equivalent length. So that type has a high potential for enhancement of heat transfer properties. [12].

\section{Experimental Details}

- $\quad$ First of all fit the multi tube (Pin type) plate in the cross flow heat exchanger shown in Figure 1.

- Switch on the cross flow heat exchanger, then switched it off.

- Note the pressure head ' $H$ ' value from the inclined manometer.
- Switch on the apparatus.

- Note the initial surface temperature of an active element.

- $\quad$ Note the active element heater voltage.

- Adjust the damper position.

- Note the initial temperature of duct air.

- Note the first reading after $5 \mathrm{~min}$ at the first position of diameter of the damper.

- Then repeat this procedure for further five holes in the multi tube plate.

- Now, after changing the damper position repeat the same procedure as above and note down the readings after every $5 \mathrm{~min}$.

- Table down all the observations for calculations.

- Then change the position of the damper and turn on the stop watch for $5 \mathrm{~min}$ and note the $2^{\text {nd }}$ reading.

- Similarly, take the other readings by changing the damper position every time.

- Note down these all observations in a table for calculation.

\subsection{Formulae Used}

$\mathrm{Q}=\mathrm{V}^{2} / \mathrm{R}$

$\Phi=\mathrm{Q} / \mathrm{A}$

' $A$ ' - is the area of the heat transfer surface $=2.482 \times$ $10^{-3} \mathrm{~m}^{2}$

$\mathrm{h}=\Phi /\left(\mathrm{T}_{\mathrm{s}}-\mathrm{T}\right)$

$\mathrm{U}=74.294 \sqrt{ } \mathrm{T}_{\mathrm{a}} * \mathrm{H} / \mathrm{P}_{\mathrm{a}}$

$\mathrm{Re}=\mathrm{Ud} / \mathrm{v}$

$\mathrm{h}=0.283(\mathrm{Re})^{0.618}$

\subsection{Observations and Calculations}

Resistance $=\mathrm{R}=68.5 \Omega$

Active element heater voltage $=\mathrm{V}=20$ volts

Diameter of active element $=\mathrm{d}=0.01586 \mathrm{~m}$

Area of heat transfer surface $=\mathrm{A}=2.482 * 10^{-3} \mathrm{~m}^{2}$

Pressure of duct air $=\mathrm{P}_{\mathrm{a}}=992 \mathrm{mbar}$

Thermal conductivity of copper at -

$352 \mathrm{~K}=396 \mathrm{~W} / \mathrm{m}-\mathrm{K}$

Observation and Calculations from position 1 to 6 are performed and their final results are shown in Table 3.

Table 1. Observations for the multi tube plate at Position 1

\begin{tabular}{|c|c|c|c|c|}
\hline Damper Position & 2 & 4 & 6 & 8 \\
\hline Active element surface temperature Ts $\left({ }^{0} \mathrm{C}\right)$ & 78.6 & 79.8 & 80.1 & 82.7 \\
\hline Duct air temperature Ta $\left({ }^{\circ} \mathrm{C}\right)$ & 17.8 & 17.9 & 18.1 & 18.5 \\
\hline Intake air depression H (mm H2O) & 24.8 & 24.8 & 24.8 & 24.8 \\
\hline Active element heater voltage $\mathrm{V}$ (volts) & 20 & 20 & 20 & 20 \\
\hline
\end{tabular}

Table 2. Calculations for the multi tube plate at Position 1

\begin{tabular}{||l|l|l|l|l||}
\hline Heat transfer rate Q $\mathbf{W})$ & 5,839 & 5,839 & 5,839 & 5,839 \\
\hline Heat flux $\boldsymbol{\Phi}(\mathbf{W} / \mathbf{m} \mathbf{)}$ & 2354,6 & 2354,6 & 2354,6 & 2354,6 \\
\hline Active element surface to air temperature difference Ta-Ts (K) & 60,8 & 60,7 & 60,5 & 60,1 \\
\hline Mean surface heat transfer coefficient $\mathbf{h} \mathbf{( W / m 2 K )}$ & 38,7269 & 38,7907 & 38,919 & 39,178 \\
\hline Duct air velocity $\mathbf{U}(\mathbf{m} / \mathbf{s})$ & 1,7993 & 1,7996 & 1,8003 & 1,8015 \\
\hline Reynolds number (Re) & 1908,676 & 1908,994 & 1909,737 & 1911,01 \\
\hline Nusselt number (Nu) & 0,00155 & 0,00155 & 0,00156 & 0,00157 \\
\hline
\end{tabular}


Table 3. Final results of positions 1 to 6

\begin{tabular}{||l|l|l|l|l|l||}
\hline \hline \multirow{3}{*}{ Position 1 } & Re No & 1908.676 & 1908.994 & 1909.737 & 1911.01 \\
\cline { 2 - 6 } & 'h' & 38.7269 & 38.7907 & 38.919 & 39.178 \\
\hline Position 2 & Re No & 1915.571 & 1916.526 & 1917.162 & 1917.586 \\
\cline { 2 - 6 } & 'h' & 52.2084 & 52.558 & 52.7937 & 52.9123 \\
\hline Position 3 & Re No & 1917.163 & 1918.223 & 1918.542 & 1918.859 \\
\cline { 2 - 6 } & 'h' & 74.227 & 74.987 & 75.226 & 75.467 \\
\hline Position 4 & Re No & 1918.542 & 1919.178 & 1920.451 & 1921.088 \\
\cline { 2 - 6 } & 'h' & 57.429 & 57.71 & 58.282 & 58.572 \\
\hline Position 5 & Re No & 1921.405 & 1921.83 & 1922.148 & 1922.784 \\
\cline { 2 - 6 } & 'h' & 57.289 & 57.429 & 57.569 & 57.852 \\
\hline Position 6 & Re No & 1922.148 & 1923.209 & 1924.209 & 1924.269 \\
\cline { 2 - 6 } & 'h' & 50.96 & 51.186 & 51.41 & 51.635 \\
\hline
\end{tabular}

\section{Simulation}

\subsection{Basic steps of simulation}

- Objective specification

- Creating geometry in Gambit

- Meshing geometry in Gambit

- $\quad$ Specifying the boundary types in Gambit

- $\quad$ Setting up the problem in FLUENT

- Solution

- Analysis and Results

\subsection{Objective Specification}

To draw the 2D grid model of the multi tube plate in the GAMBIT 2.3.16 version and then set up this objective on the FLUENT 6.3.26 version. Reynolds number is 1908.7 and the heating element temperature is $352 \mathrm{~K}$.

Creating geometry in GAMBIT:

- Start the GAMBIT 2.3 .16 by creating new working directory 'single tube plate'.

- From the main menu select solver and then FLUENT as the mesh to be created will be used in the FLUENT 6.3.26 version.

From the operation tool pad select the geometry and then the following vertices are created.

Fig. 2 shows the mesh of the multi tube plate which shows the staggered arrangement.

\subsection{Setting up the objective in FLUENT}

After meshing, the problem is set up on FLUENT and Fig. 3 is displaying the grid of the multi-tube plate on FLUENT.

\subsection{Post-processing}

- Display the contours of static pressure, static temperature and velocity.

- Display the velocity vectors.

- Create the iso-surfaces, by giving the $\mathrm{x}$ coordinate values of $0.01,0.015,0.02,0.025$, 0.03 and 0.035 for position-1, position-2, position-3, position-4, position-5 and position-6, respectively.

- Draw the XY plots of static temperature, static pressure, velocity, surface heat transfer coefficient, surface Nusselts number, Reynolds number and wall fluxes.

- Also draw the XY plots of static temperature, static pressure and velocity position wise.

\section{Results and Discussions}

\section{Position 1:}

Graphical representation of the effect of Re no on the surface heat transfer coefficient is shown in Fig. 4.

This is for position 1 of the multi tube plate. And at position 1 the turbulence is minimal as it is the initial point, the value of $\operatorname{Re}$ no is also low, and the same is for a heat transfer coefficient. 


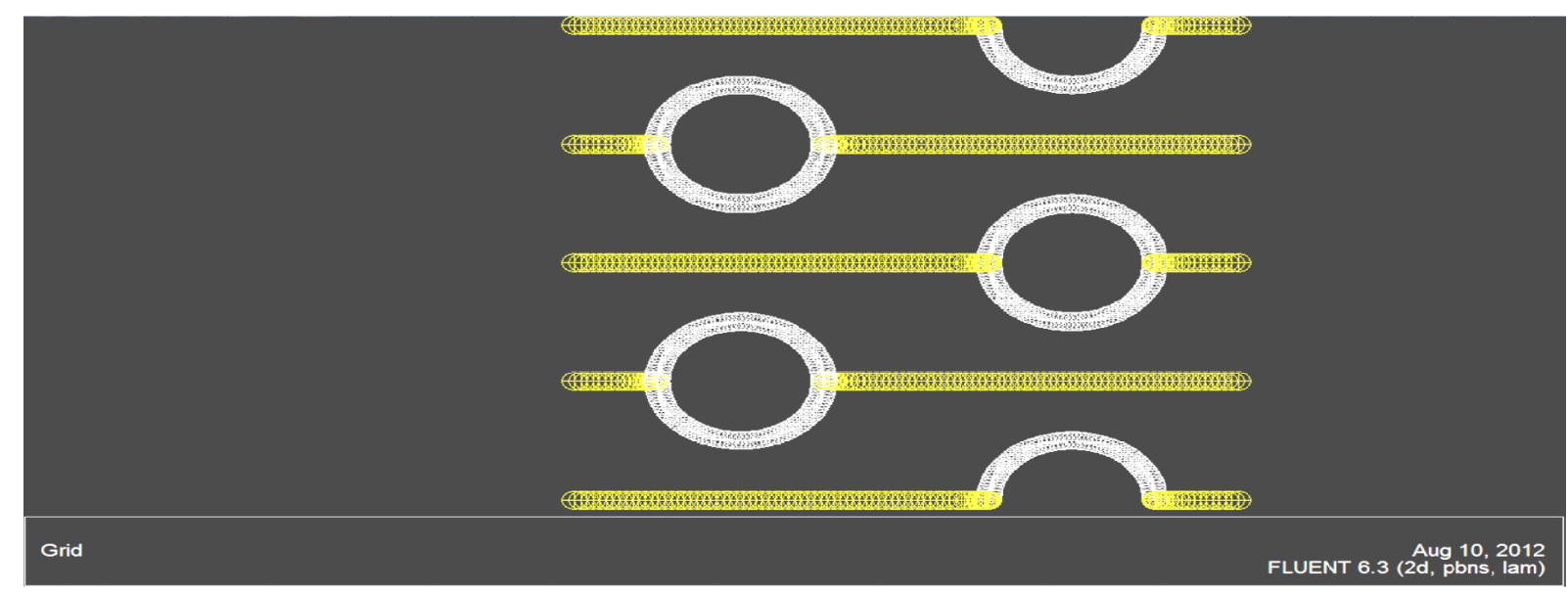

Fig. 2. Mesh of the multi tube plate

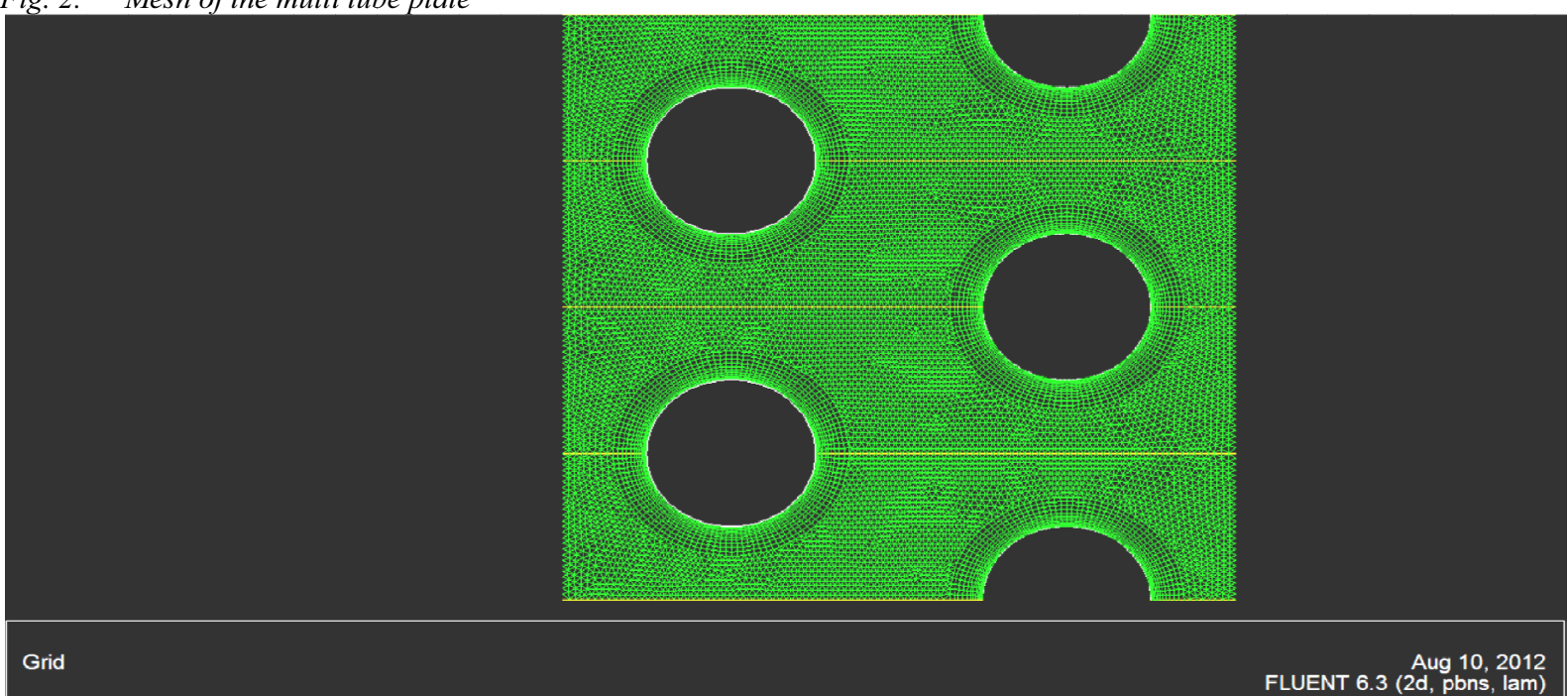

Fig. 3. Grid display for the multi tube plate on FLUENT

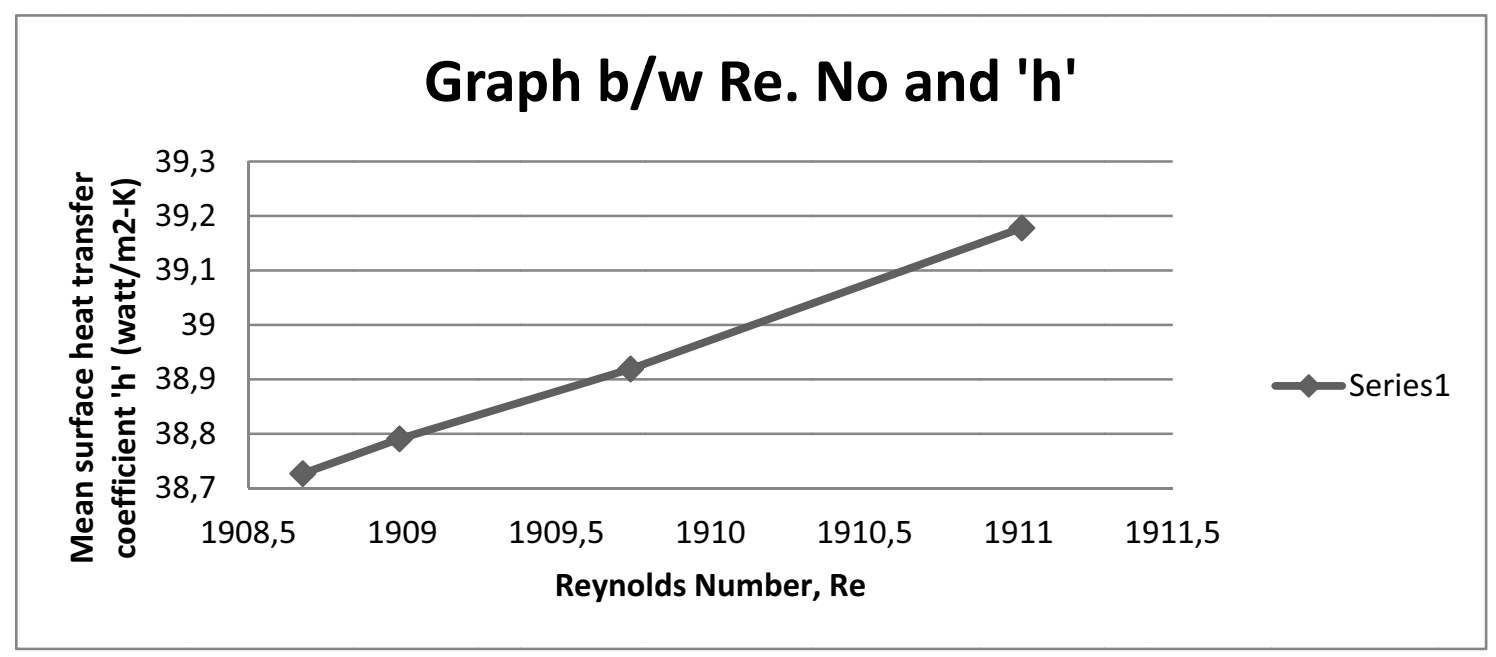

Fig. 4. Graph between Reynolds Number and ' $h$ '(Position 1)

\section{Position 1 to 6:}

Fig. 5 shows the effect of Re no on the surface heat transfer coefficient throughout the multi tube plate (pin type). It is visible from the graph that the heat transfer is high at the center of the plate; at positions 3,4 , and 5 . It means that with an increase in turbulence, the air residence time increases, which ultimately increases the rate of heat transfer.
After analyzing and solving the grid of the flat plate on the FLUENT 6.3.26 the following results are obtained:

Fig.6 shows the contours of velocity magnitude for the multi tube plate. Velocity is high close to the tubes due to high pressure, and then it decreases. 
Fig. 7 and 8 show the velocity vectors of the multi tube plate. These velocity vectors are colored by velocity magnitudes.

Fig. 9 shows the contours of Reynolds number for the multi tube plate. Velocity and Reynolds number are directly related therefore contours are also similar there.

Fig. 10 shows the plots of velocity magnitude at all six positions of the multi-tube plate. The maximum turbulence is shown at the center of the multi-tube plate at positions 3,4 \& 5. Fig. 11 shows the surface heat transfer for the multi-tube plate from positions 1 to 6 . It shows a heat transfer coefficient is directly related to the turbulence.

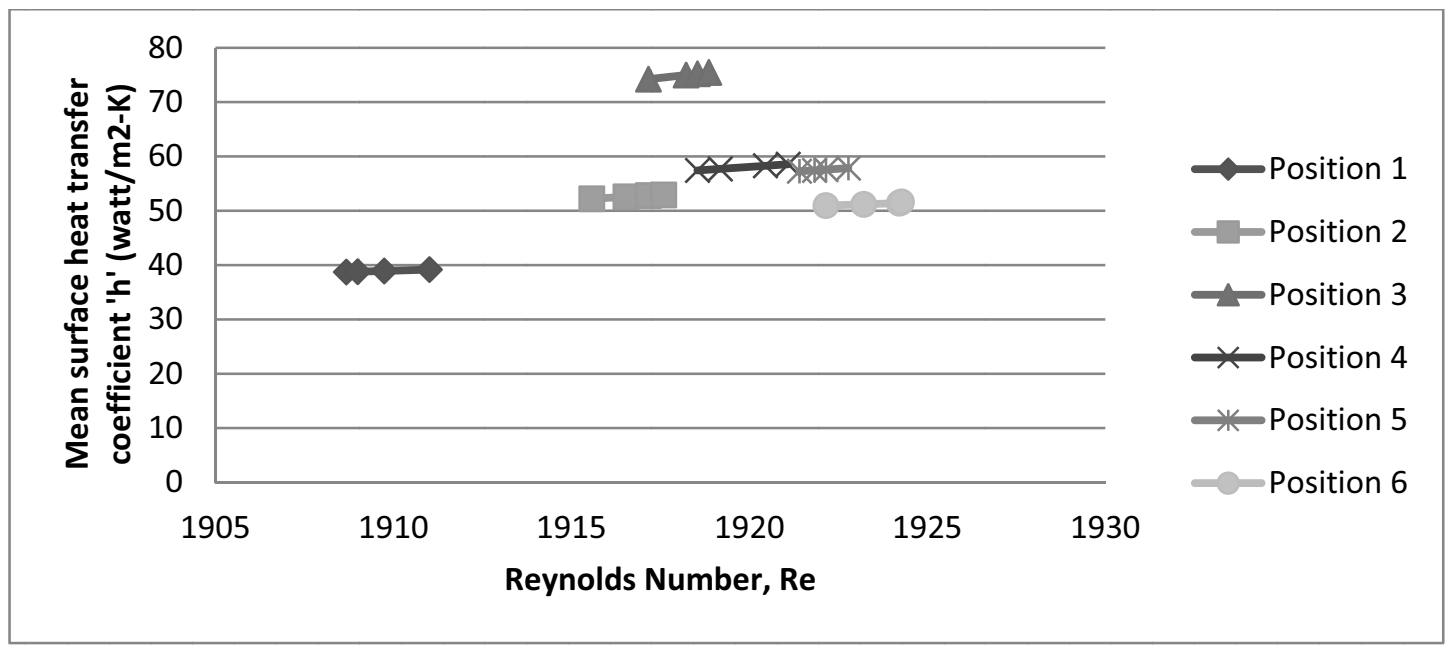

Fig. 5. Graph between Reynolds Number and ' $h$ '

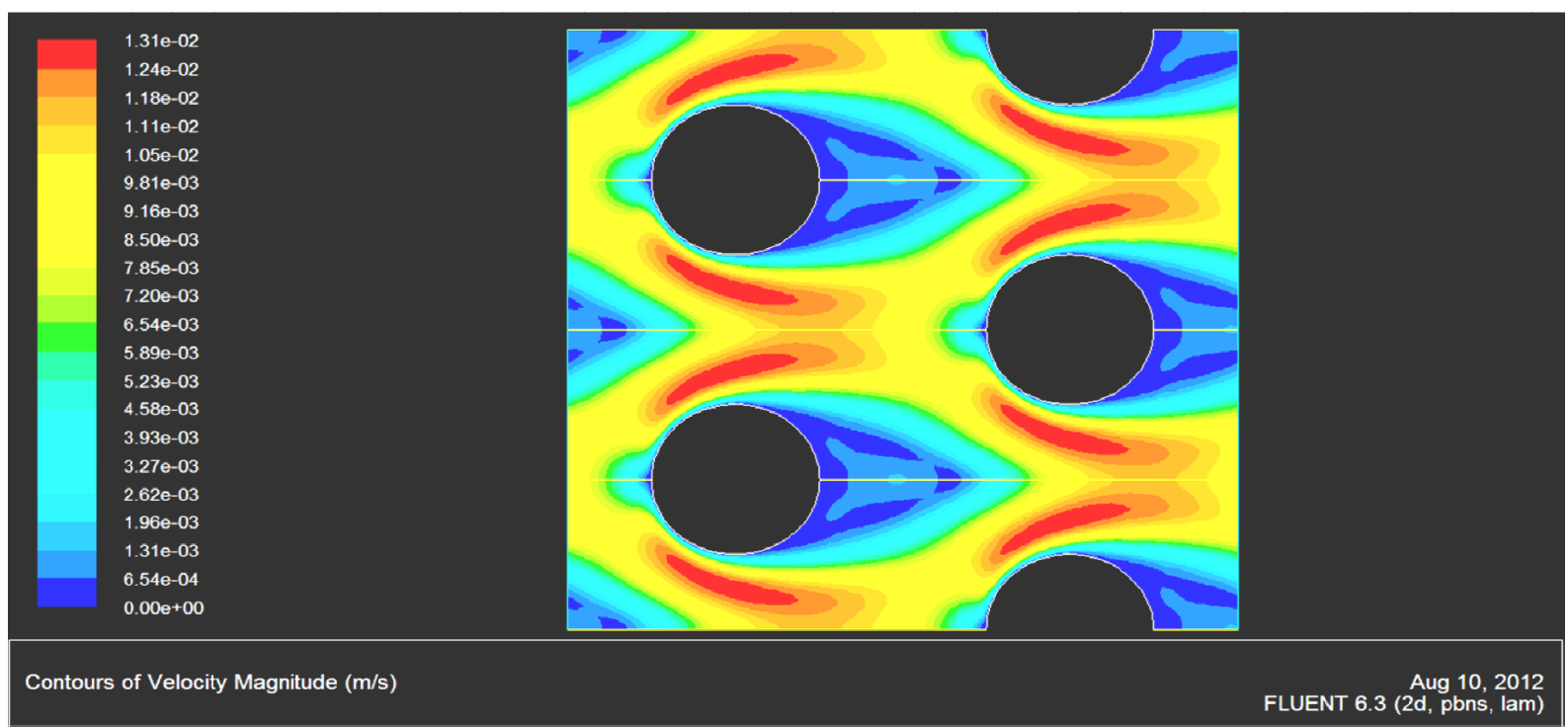

Fig. 6. Contours of velocity magnitude for the multi tube plate 


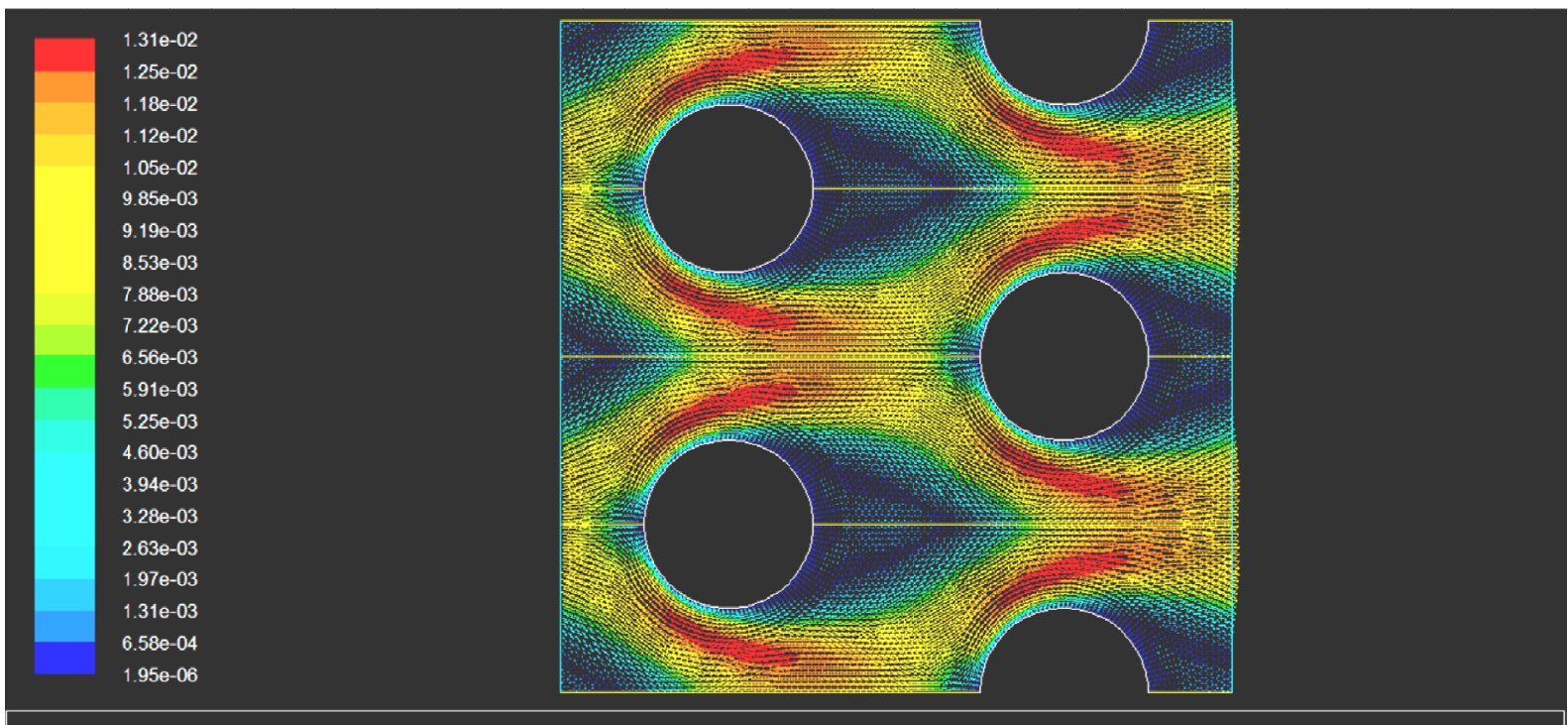

Velocity Vectors Colored By Velocity Magnitude $(\mathrm{m} / \mathrm{s})$

Aug 10, 2012

Fig.7. Velocity vectors of the multi tube plate along the symmetry

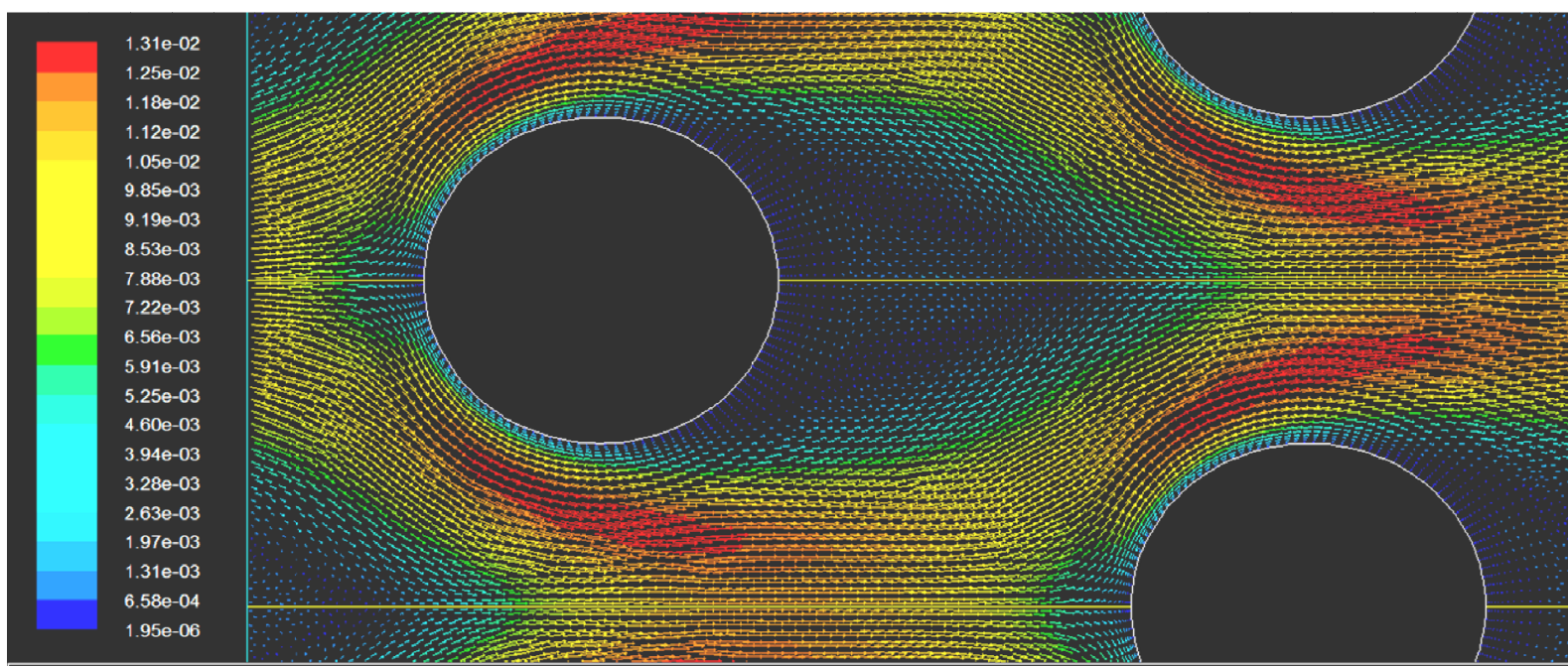

Velocity Vectors Colored By Velocity Magnitude $(\mathrm{m} / \mathrm{s})$

Aug 10, 2012
FLUENT 6.3 (2d, pbns, lam)

Fig. 8. Velocity vectors of the multi tube plate (zoomed)

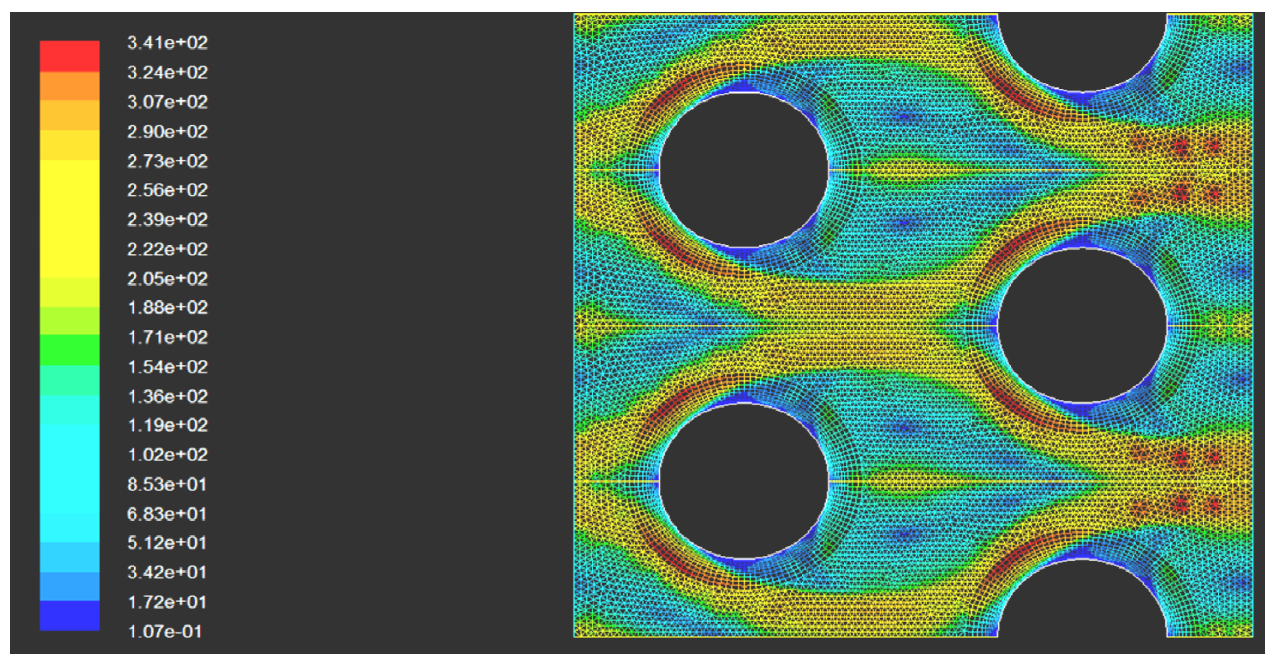

Contours of Cell Reynolds Number

Fig. 9. Contours of Reynolds number for the multi tube plate 


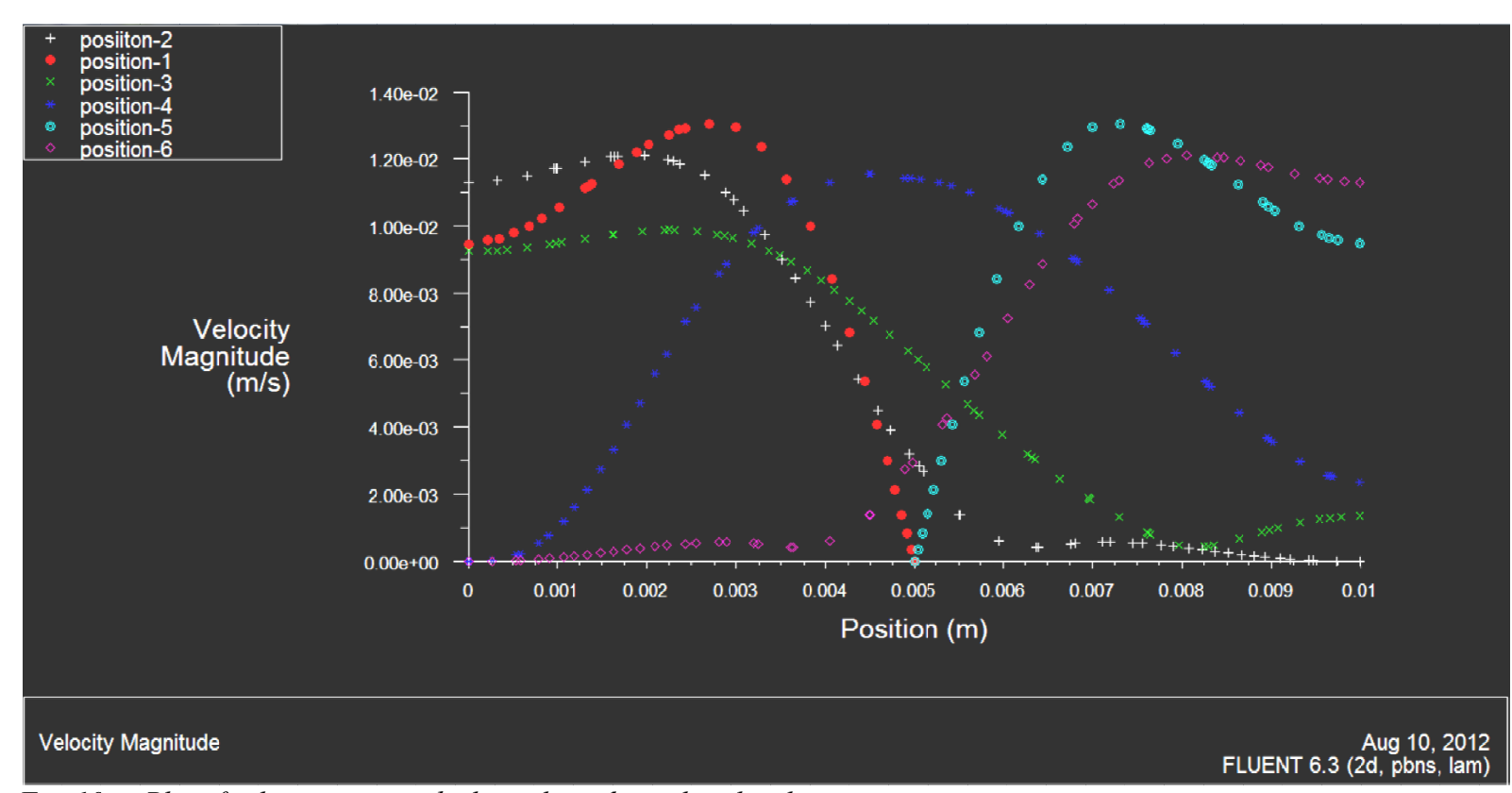

Fig. 10. Plot of velocity magnitude throughout the multi tube plate

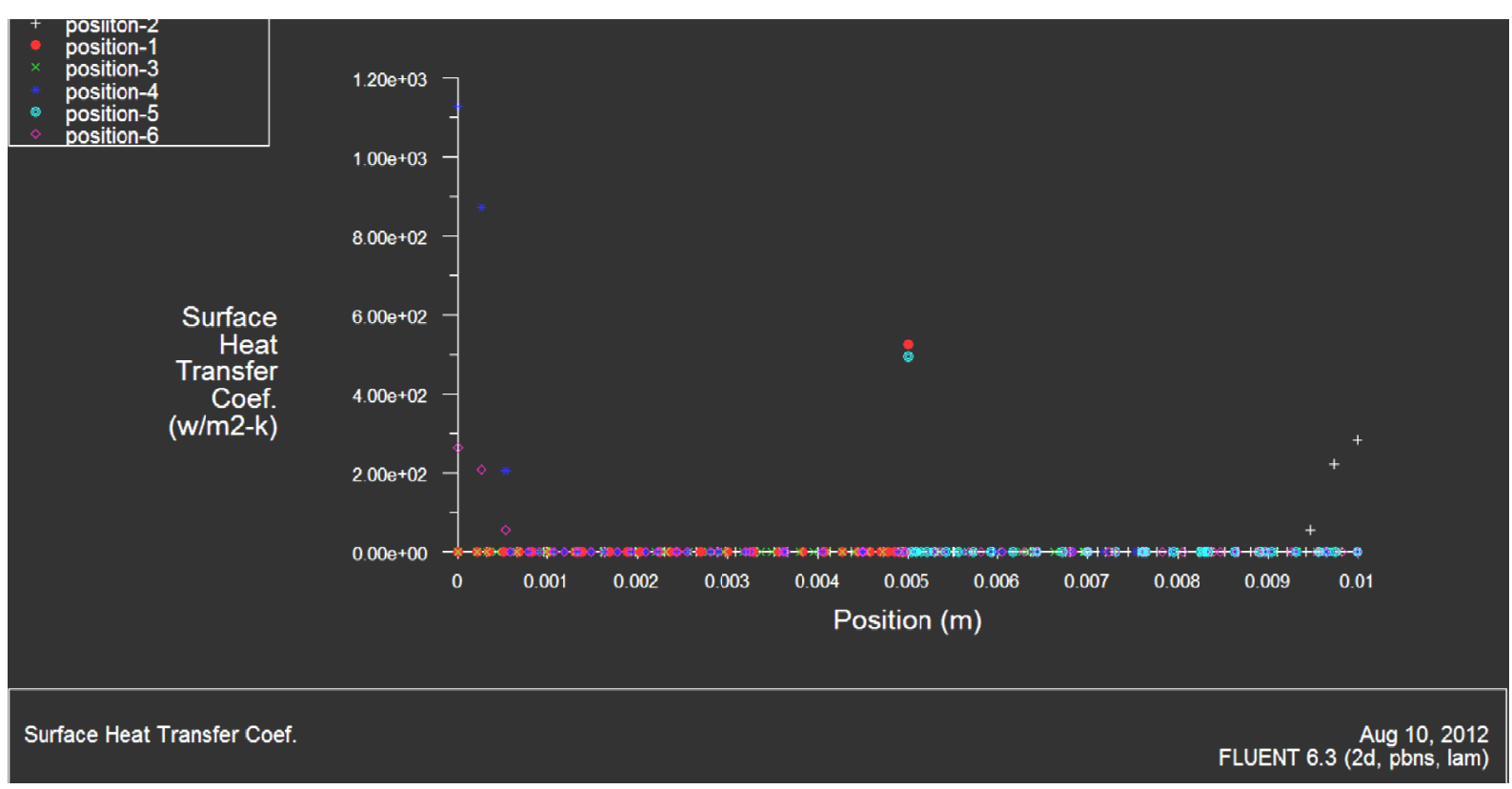

Fig. 11. Surface heat transfer coefficient throughout the multi tube plate

\subsection{Comparison of experimental and simulated results}

In a case of the multi tube plate, experimental results show that the maximum heat transfer is at positions $3 \& 4$, because here the number of tubes are more due to which turbulence and residence time of air increases and simulated results show that the heat transfer at positions 3
$\& 4$ is high, but at position 5 there is the highest value of a heat transfer coefficient, which falls suddenly. From xy plots it is clear that velocity of the air, turbulence and the surface heat transfer coefficient are high at the center of the plate. Simulated results like the experimental ones show the direct relationship between $\mathrm{Nu}$ and Re. 


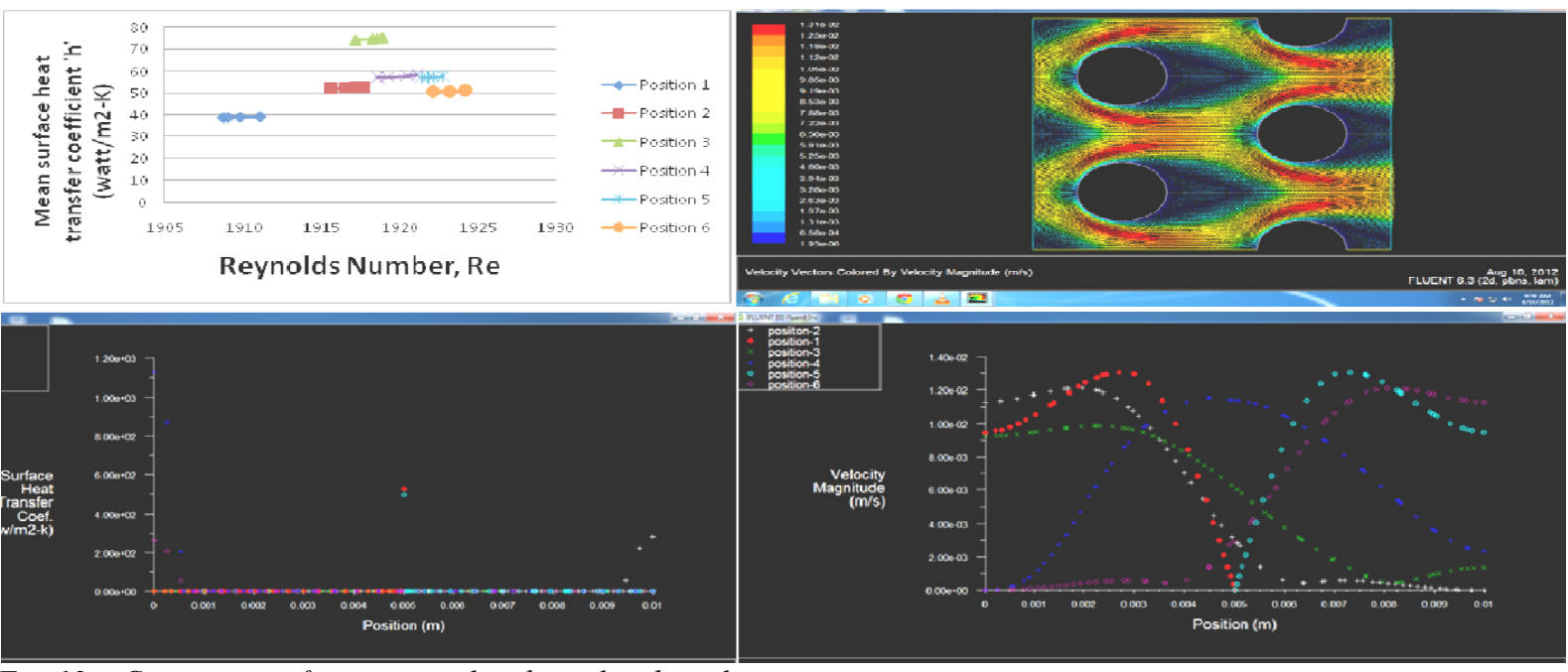

Fig. 12. Comparison of experimental and simulated results

\subsection{Mathematical Modeling/Empirical relationship development}

Development of mathematical models is the science of generating workable correlations through experimental data. Different mathematical models taken from the literature concerned have been studied. Some of them and their comparison with this study are as follows:

Dittus - Boelter ${ }^{[13]}$ gave the theoretical model for forced convection as follows:

$\mathrm{Nu}=0.023 \operatorname{Re}^{0.8} \operatorname{Pr}^{0.4}$

McAdams ${ }^{[14]}$ presented the following model:

$\mathrm{Nu}=0.37 \mathrm{Re}^{0.6}$

Sieder \& Tate ${ }^{[15]}$ presented following equation:

$\mathrm{Nu}=0.027 \operatorname{Re}^{0.8} \operatorname{Pr}^{0.3}\left(\mu / \mu_{\mathrm{s}}\right)^{0.14}$

Zukauskas ${ }^{[16]}$ model equation is as follows:

$\mathrm{Nu}=0.283 \operatorname{Re}^{0.61} \operatorname{Pr}^{0.36}\left(\operatorname{Pr} / \operatorname{Pr}_{\mathrm{w}}\right)^{0.25}$

$\mathrm{Kern}^{[17]}$ presented the equation in terms of the hydraulic mean diameter for the flow parallel to the tubes

$\mathrm{Nu}=0.36(\mathrm{Re})^{0.55}(\operatorname{Pr})^{0.33}\left(\mu / \mu_{\mathrm{s}}\right)^{0.14}$

Multi Tube Plate:

Position 1 of the multi tube plate the model developed is:

$\mathrm{Nu}=0.365 \mathrm{Re}^{0.618}$

Position 2:

$\mathrm{Nu}=0.492 \mathrm{Re}^{0.618}$

Position 3:

$\mathrm{Nu}=0.70 \mathrm{Re}^{0.618}$

Position 4:

$\mathrm{Nu}=0.54 \mathrm{Re}^{0.618}$

Position 5:

$\mathrm{Nu}=0.54 \mathrm{Re}^{0.618}$

Position 6:

$\mathrm{Nu}=0.29 \operatorname{Re}^{0.618}$

Comparing with Dittus - Boelter' model, $62 \%$ of the change will be required to enhance the heat transfer coefficient to $100 \%$ instead of $80 \%$ at all positions of the multi tube plate.

The same is the case with Sieder \& Tate' model, when it reduced to non-viscous fluid.
Comparing with McAdams' model, the model developed at position 1 is exactly matching it, but at other positions it starts differentiating.

Kern' model is for the flow parallel to the tubes therefore it does not apply here.

Zukauskas' model when reduced to the non viscous flow is an exact match of the model developed at position 6 of the multi tube plate.

In a case of the multi tube plate, two models from the theoretical literature match exactly the models developed experimentally.

\section{Conclusions}

- Experimental results show that Surface heat transfer coefficient and Reynolds number directly related and the maximum heat transfer takes place in the center of the tube arrangement at positions $3 \& 4$.

- Experimental results also illustrate that Nusselts number is directly related to Reynolds number, which validates the fact that $\mathrm{Nu}$ is a function of $\mathrm{Re}$ for forced convection.

- $\quad$ Simulated results validate the experimental data.

- Both results show that the maximum heat transfer is at positions $3 \& 4$, which is 75.467 and $58.572 \mathrm{~W} / \mathrm{m}^{2} \mathrm{~K}$ respectively.

- $\quad \mathrm{Nu}$ also confirms the above behavior by showing the maximum value at positions $3 \& 4$; which is 0.00302 and 0.00235 respectively.

- For the multi tube plate the value of velocity or Re no is high at positions 3 and 4 of the tube arrangement, which is quite visible from the plot of velocity magnitude.

- It is concluded for the multi tube plate that surface heat transfer coefficient and $\mathrm{Nu}$ are also high at positions $3 \& 4$, for this reason simulated results validate the experimental ones.

- Mathematical models have developed for the multi tube plate at each position and the models developed at position 1 and position 6 match exactly McAdams' and Zukauskas' models found in literature, respectively. For the multi tube 
plate the experimental data are matching those found in literature.

\section{Future Recommendations}

The following recommendations can be helpful for future research purposes:

- All the experimental data collected are for nonviscous fluid. The equipment can be modified for viscous fluids.

- All the calculations are made just keeping in view the convection mode only, conduction and radiation modes can also be considered.

- $\quad$ The present version of the GAMBIT 2.3.16 has the limitation for animations which can be studied through its advanced version.

- The geometry of a multi fin plate used in this study cannot be made on the GAMBIT 2.3.16, for this Cubit software can be used.

- $\quad$ FLUENT is used for the analysis, so even plate geometry can be changed for best results.

\section{List of Symbols:}

$\mathrm{T}_{\mathrm{s}}=$ Surface temperature of heating element, ${ }^{\circ} \mathrm{C}$

$\mathrm{T}_{\mathrm{a}}=$ Duct air temperature, ${ }^{\circ} \mathrm{C}$

$\mathrm{V}=$ Voltage of heating element, Volts

$\mathrm{R}=$ Resistance of heating element, Ohms

$d=$ Diameter of heating element, $m$

$A=$ Area of heat transfer surface, $\mathrm{m}^{2}$

$\mathrm{Q}=$ Heat transfer rate, Watt

$\Phi=$ Heat flux, Watt $/ \mathrm{m}^{2}$

$\mathrm{H}=$ Suction head or Intake air depression, $\mathrm{mmH}_{2} \mathrm{O}$

$\mathrm{P}_{\mathrm{a}}=$ Pressure of air, mbar

$\mathrm{K}=$ Thermal Conductivity of heating element, $\mathrm{W} / \mathrm{m}-\mathrm{K}$

$\mathrm{U}=$ Duct air velocity, $\mathrm{m} / \mathrm{s}$

$\mathrm{h}=$ Surface heat transfer coefficient, $\mathrm{W} / \mathrm{m}^{2}-\mathrm{K}$

$v=$ Kinematic Viscosity of air, $\mathrm{m}^{2} / \mathrm{sec}$

$\mu=$ Absolute viscosity of air, $\mathrm{kg} / \mathrm{m}$-sec

$\mathrm{Cp}=$ Specific heat of air, $\mathrm{kJ} / \mathrm{kg}-\mathrm{K}$

$\mathrm{Re}=$ Reynolds Number, $\mathrm{d} U / \mathrm{v}$

$\mathrm{Nu}=$ Nusselts Number, $\mathrm{hd} / \mathrm{K}$

$\operatorname{Pr}=$ Prandtle Number, $\mathrm{Cp} \mu / \mathrm{K}$

\section{References}

Kim, M., Baik, Y., Park, S., Ra, H., and Lim, H., "Experimental Study on Corrugated Cross-flow Air-cooled Plate Heat Exchangers", Experimental Thermal and Fluid Science $\quad 34 \quad$ (2010) 1265-1272. http://dx.doi.org/10.1016/j.expthermflusci.2010.05.007

Wen, J., Li, Y., Zhou, A., and Zhang, K., "An Experimental and Numerical Investigation of Flow Patterns in the Entrance of Plate-fin Heat Exchanger", International Journal of Heat and Mass Transfer 49 (2006) 1667-1678. http://dx.doi.org/10.1016/j.ijheatmasstransfer.2005.10.029

Yoon, Y. H., Paeng, J. G., and Kim, K. C., "A Theoretical Analysis and CFD Simulation on the Ceramic Monolith Heat Exchanger", $10^{\text {th }}$ International Conference on Fluid Control, Measurements, and Visualization, August 17-21, 2009, Moscow, Russia.

Cabezas-Gomez, L., Navarro, H. A., De Godoy, S. M., Campo, A., and Saiz-Jabardo, J. M., "Thermal characterization of a cross-flow heat exchanger with new flow arrangement", International Journal of Thermal $\begin{array}{llll}\text { Sciences } & 48 & \text { (2009) }\end{array}$ http://dx.doi.org/10.1016/j.ijthermalsci.2009.03.015

Clark, W., and DiBiasio, D., "Computer Simulation for Laboratory Experiments for Enhanced Learning", American Society for Engineering Education, (2007).

Zhang, G., Tian, M., and Zhou, S., "Simulation and Analysis of Flow Pattern in Cross-Corrugated Plate Heat Exchangers", Journal of Hydrodynamics, Ser. B, 2006, 18(5): $\quad 547-551 . \quad \mathrm{http}: / / \mathrm{dx}$. doi.org/10.1016/S10016058(06)60133-9

Liang, C., and Papadakis, G., "Large Eddy Simulation of Cross-flow through a Staggered Tube bundle at subcritical Reynolds number", Journal of Fluids and $\begin{array}{llll}\text { Structures } & 23, \quad \text { (2007), }\end{array}$ http://dx.doi.org/10.1016/j.jfluidstructs.2007.05.004

Saber, M. H., and Ashtiani, H. M., "Simulation and CFD Analysis of Heat Pipe Heat Exchanger using Fluent to increase the Thermal Efficiency", 2008, ISSN: 1790-5095, ISBN: 978-960-474-158-8.

Egeregor, D., "Numerical Simulaiton of Heat Transfer and Pressure Drop in Plate Heat Exchangers using FLUENT as CFD Tool", Department of Mechanical Engineering, Blekinge Institute of Technology, Karlskrona, Sweeden. (2008).

Vali, A., Simonson, C. J., Besant, R. W., and Mahmood, G., "Numerical Model and Effectiveness Correlations for a Run-around Heat Recovery System with Combined Counter and Cross Flow Exchangers", International Journal of Heat and Mass Transfer 52 (2009) $5827-5840$.

http://dx.doi.org/10.1016/j.ijheatmasstransfer.2009.07.020

Dehghandokht, M., Khan, M. G., Fartaj, A., and Sanaye, S., "Flow and heat transfer characteristics of water and ethylene glycol-water in a multi-port serpentine mesochannel heat exchanger", International Journal of Thermal $\begin{array}{llll}\text { Sciences } & 50 & \text { (2011) }\end{array}$ http://dx.doi.org/10.1016/j.ijthermalsci.2011.03.004

Mori, H., "Enhancement of Heat Transfer for Ground Source Heat Pump Systems", Thesis submitted to the University of Nottingham for the degree of Doctor of Philosophy, October 2010.

Dittus, P. W., and L. M. K. Boelter, Univ. Calif. Pub. Eng., Vol. 2, No. 13, pp. 443-461 (1930), reprinted in Int. Comm. Heat Mass Transfer, Vol. 12, pp. 3-22 (1985). http://dx.doi.org/10.1016/0735-1933(85)90003-X

McAdams, W. H., 1954, Heat Transmission, McGraw-Hill, New York.

Sieder, E. N. and Tate, G. E., 1936, "Heat Transfer and Pressure Drop of Liquids in Tubes", Ind. Eng. Chem., Vol. 28, $\quad$ pp. $1429 \quad-1436$. http://dx.doi.org/10.1021/ie50324a027

Žukauskas, A., "Heat Transfer from Tubes in Cross Flow," Advances in Heat Transfer, Vol. 8, 1972, pp. 93160. http://dx.doi.org/10.1016/S0065-2717(08)70038-8

Kern D.Q., "Process Heat Transfer", Mc Graw-Hill pp. 46-53, 1950. 
Suneela Sardar - lecturer at NFC Institute of Engineering and Fertilizer Research in Chemical Engineering Department.

Main Research Area: Heat Transfer, Simulation, Renewable Energy, Composting.

Address NFC Institute of Engineering and Fertilizer Research, Faisalabad, Pakistan

Tel: $\quad$ +92-321-6673505

Email: suneelasardar@yahoo.com
Ph.D Shahid Raza Malik - Director, NFC Institute of Engineering and Fertilizer Research and HOD Chemical Engineering Department/

Main Research Area: Gasification, Heat Transfer, Coal Technology, Energy Engineering

Address: NFC Institute of Engineering and Fertilizer Research, Faisalabad, Pakistan

Tel: $\quad$ +92-333-8398838

Email: drsrma@yahoo.com

\title{
Priešpriešinio srauto, daugiavamzdžio šilumokaičio modeliavimas naudojant programą FLUENT 6.3.26
}

\author{
Suneela Sardar, Shahid Raza Malik \\ NFC Inžinerijos ir trąšu moksliniu tyrimu institutas (IEFR), Pakistanas
}

(gauta 2013 m. gegužès mèn.; atiduota spaudai 2013 m. rugsèjo mèn.)

Chemijos inžinerijos srityje yra nemažai nuveikta norint praplèsti įvairiu procesų modeliavimo ribas. Kompiuterinis modeliavimas yra plačiai naudojamas šiandieniniuose tyrimuose tiek realiajai, tiek virtualiajai proceso elgsenai prognozuoti. Šiame darbe buvo vykdomas praktinis eksperimentas, modeliuojami gauti duomenys ir toliau plètojamas modelis. Šilumos perdavimo koeficientas vertinamas atliekant eksperimentą su daugiavamzdžio sluoksnio priešpriešinių srautu šilumokaičiu. Gavus eksperimento rezultatus atliekamas modeliavimas. Projektuoti ir plokštumoms geometriškai sulieti buvo naudojama programa GABIT 2.3.16, o duomenu analizei atlikti - programa FLUENT 6.3.26. Lyginant eksperimentinius ir modeliavimo rezultatus, buvo nustatyta, kad eksperimento ir modeliavimo rezultatai, esant nedideliam nuokrypiui, sutampa. Taip pat matematiškai buvo nustatytas Reinoldso (Re) ir Nuselto $(\mathrm{Nu})$ skaičiu ryšys ir palygintas su teoriniais mokslinèje literatūroje pateikiamais modeliais. Rezultatai parodè, kad sukurtas modelis atitinka teorinius modelius. Rekomenduojama ateityje atlikti mokslinius tyrimus naudojant klampius skysčius ir patobulintą programinę ịrangą Cubit, kuri skirta sluoksnių geometrijai projektuoti ir sulieti. 